\title{
Transformation of water supply of population and economic objects in the Don River basin for the period of $1990-2018$
}

\author{
Alexander Demin, and Anna Zaitseva* \\ Institute of Water Problems of Russian academy of Sciences, 119333 Moscow, 3 Gubkina St., Russia
}

\begin{abstract}
The analysis of the current state of major water consumers and water complex participants is performed. The data on the increase in centralized water supply of the residential accommodation during 20002018 is presented. Significant decrease in the volume of water used for drinking water supply is shown. The improvement of water quality in water bodies of most regions is revealed. The use of fresh water for production needs in the Don River basin decreased from 5.8 to $2.9 \mathrm{~km}^{3}$ from 1990 to 2018. The water circulation coefficient in industry increased from 64 to $85 \%$. The area of irrigated lands in the basin has started to decrease significantly since 1990. In 2000 every second hectare of available irrigated land was watered and in 2016 only every fourth was watered.
\end{abstract}

\section{Introduction}

Considering economic development, the Don River basin is the most important region of Russia. More than 12 million people live there, and population density of the region is 4.5 times higher than average in Russia. The problem of providing the population and economic facilities with water resources of adequate quality in the required mode is acute on this territory. The region is characterized by a high level of industrialization and a developed transport and communication infrastructure. Favorable transport and geographical location, natural and demographic conditions provided the great potential for socio-economic development of the region.

However, further development of the region is hindered by the growing shortage of water resources. In the Don River basin the established diversified water management complex is functioning. This complex consists of water supply of all categories, including industrial (thermal and nuclear power plants), municipal and agricultural water supply, as well as pasture irrigation, irrigated agriculture, fisheries (artificial and natural, commercial, reproduction of fish stocks pond fish farming), water transport, and hydropower. The value of the total irretrievable withdrawal of runoff at the current level of the state of water management complex practically corresponds to the value of the permissible irrevocable runoff intake.

\footnotetext{
* Corresponding author: yew-tree@mail.ru
} 
The work objective is to reveal the changes in the conditions of water supply and water consumption volume by the population and economic objects in the Don River basin for a long period of time.

\section{Materials and methods}

Data from the Federal State Statistics Service was used as the initial materials. The following data includes official statistical information about the municipal improvement of Russian regions, the volume of water supply networks put into operation, the deterioration of the water supply network for all constituent entities for 2000-2018, and the volumes of water passed through preliminary treatment. The share of leaks and unaccounted costs in the total volume of water supplied to the network for all entities for this period were calculated using the information on the volumes of leaks and water discharged to consumers. The analysis of the groundwater use for drinking water supply was based on materials from newsletters about the subsoil resources state of the Federal Subsoil Resources Management Agency.

To calculate the indicators of specific use of water for drinking, production, industrial water supply and irrigation, statistical materials from the Federal Agency for Water Resources were used. The Agency also provided information on the volume of water discharge in the circulating and water recycling systems. The calculation of the modern supply of apartments with cold and hot water meters was based on the materials of the statistical digests "Residential Sector in Russia".

Assessment of the water quality in drinking water supply sources, as well as the availability of drinking water, meeting safety requirements for the population, was based on the materials of the territorial bodies of Russian Federal Service for Surveillance on Consumer Rights Protection and Human Wellbeing. Information on the availability of irrigated land area, the area of actually watered land by federal subjects was obtained in the Land Melioration Cadastre, which has been maintained by the Land Melioration Department of the Ministry of Agriculture of the Russian Federation for a long time.

\section{Results and Discussion}

In $2018,100 \%$ of cities, $85-95 \%$ of urban settlements and $35-85 \%$ of rural settlements of constituent entities of Russian Federation in the Don River basin were provided with centralized water supply services. $92 \%$ of residents in the Stavropol Territory used centralized water supply services. This was the maximum value of all constituent entities in the Don River basin. In Voronezh, Kursk, Oryol, Tambov and Saratov regions the use of centralized water supply services currently has not exceeded $80 \%$. It has not exceeded $60 \%$ in the Republic of Kalmykia. The share of available housing fitted with water supply systems has grown rather slowly [1, 2, 3]. From 2000 to 2018 in most regions it increased by 13-19 percentage points (p.p.). In Belgorod, Voronezh and Tambov regions it increased by more than 20 p.p., and in Tula, Saratov regions and Krasnodar Territory it grew only by 4-9 p.p.

In urban areas the proportion of available housing provided with centralized water supply is significantly higher than in rural areas. In 2018 in all of the constituent entities of the Don River basin, except the Republic of Kalmykia, it exceeded 85\%, and in Stavropol Territory it was $95.6 \%$. The rural areas are characterized by extreme diversity in provision with centralized water supply systems. It varies from $34 \%$ in the Republic of Kalmykia to $85 \%$ in Stavropol Territory. As a whole in the Don River basin the provision of rural 
residents with water supply systems is lower by 24 percentage points than the later of urban and rural settlements' residents.

The volumes of putting into service of new water supply networks are very low and have decreased several times compared to the beginning of the 1990s. As a result, the volumes of the water supply networks needed for replacement sharply increased over the years. In 2005 the share of water supply networks needed for replacement varied among the constituent entities of the Don River basin from 26\% (Kursk and Penza regions) to 50\% (Republic of Kalmykia). In 2018 in Kursk, Ryazan, Tula regions 48\% of the water supply networks were necessary to be replaced. In Voronezh region and the Republic of Kalmykia this value was $50 \%$, and in Lipetsk region it was $69 \%$.

The growing deterioration of water supply networks is the main reason for the increase in the share of leaks and unaccounted water consumption in relation to the volume of water supplied to the network. In 2000 in three of fifteen constituent entities, located in the Don River basin, the proportion of leaks exceeded $20 \%$, and in three constituent entities it was below $10 \%$ [4]. For the period of 2000-2018 in six constituent entities of Russian Federation the share of leaks in the total amount of water supplied to the network grew by 11-20 p.p. In Tula region and the Republic of Kalmykia it increased by 22-27 p.p., and in Saratov region it grew by 30 p.p. The highest share of leaks in 2018 was noted in Tula and Saratov regions (38\%), as well as in the Stavropol Territory, where about $41 \%$ of water was lost in leaky networks. It should be noted that significant financial resources were spent on the water treatment and delivery. A relatively small proportion of leaks was observed in Kursk and Orel regions (13-17\%).

In the vast majority of the Upper Don regions, the entire population uses water from groundwater sources for drinking water supply. This is an encouraging fact, since groundwater is protected from pollution better than surface water. However, currently in Rostov Region and Stavropol Territory only every fifth resident uses water from groundwater sources, and in Volgograd Region this value is less than 10\%. From 2001 to 2017, the volume of groundwater use for drinking water supply decreased in most constituent entities of the Don River basin by 1.5-2.5 times [5, 6].

In the Don River basin a strong differentiation in water pre-treatment is observed. In the Orel region, water is not treated at all. In 2018 in Kursk and Lipetsk region only 1-4\% of drinking water was pre-treated. This can be explained by the fact that water was taken from deep groundwater aquifers with high quality. At the same time, in the Belgorod, Voronezh, Tambov and Tula regions, almost $100 \%$ of the population also uses groundwater, however the amount of preliminary treated groundwater varied from $26 \%$ of the total withdrawn groundwater (Belgorod region) to 59-67\% (other regions). The residents of the Republic of Kalmykia are in the worst situation, because only about $7 \%$ of the total volume of water is pre-treated, although almost half of the resources for drinking water are taken from surface sources.

An integrated index of water supply of the population is the volume of water use for drinking water supply. The maximum value of this index in the Don River basin was noted in 1990, later it was constantly decreasing. In recent years in the regions water meters have being actively introduced and other series of water-saving measures have been taken to rationally use water in the available housing using the budgetary funds, extra-budgetary sources, and loans. As a result, the volume of water use for drinking water supply is rapidly decreasing (Table). 
Table. The dynamics of the specific water use for drinking water supply of the population of constituent entities of Russian Federation in the Don River basin, 1 litter/day per person.

\begin{tabular}{|c|c|c|c|c|c|c|c|c|}
\hline Constituent entitiy & $\mathbf{1 9 9 0}$ & $\mathbf{1 9 9 5}$ & $\mathbf{2 0 0 0}$ & $\mathbf{2 0 0 5}$ & $\mathbf{2 0 1 0}$ & $\mathbf{2 0 1 5}$ & $\mathbf{2 0 1 8}$ & $\begin{array}{c}\mathbf{2 0 1 8} \text { to } \\
\mathbf{1 9 9 0 ,}\end{array}$ \\
\hline Belgorod region & 195 & 176 & 200 & 203 & 183 & 167 & 173 & 89 \\
\hline Voronezh region & 213 & 226 & 234 & 228 & 209 & 151 & 149 & 70 \\
\hline Kursk region & 173 & 123 & 153 & 185 & 132 & 112 & 109 & 63 \\
\hline Lipetsk region & 242 & 255 & 276 & 259 & 203 & 147 & 146 & 60 \\
\hline Orlov region & 186 & 167 & 240 & 251 & 186 & 136 & 140 & 75 \\
\hline Ryazan o region & 241 & 262 & 231 & 247 & 197 & 167 & 167 & 69 \\
\hline Tambov region & 173 & 165 & 179 & 248 & 174 & 143 & 156 & 90 \\
\hline Tula region & 325 & 308 & 278 & 274 & 235 & 183 & 174 & 53 \\
\hline $\begin{array}{c}\text { Republic of } \\
\text { Kalmykia }\end{array}$ & 101 & 99 & 70 & 72 & 72 & 71 & 66 & 65 \\
\hline Krasnodar Territory & 232 & 200 & 213 & 152 & 138 & 124 & 133 & 57 \\
\hline Volgograd region & 313 & 302 & 285 & 243 & 280 & 224 & 195 & 62 \\
\hline Rostov region & 232 & 199 & 194 & 155 & 154 & 123 & 117 & 50 \\
\hline Stavropol Territory & 223 & 217 & 163 & 118 & 95 & 95 & 89 & 40 \\
\hline Penza region & 188 & 161 & 222 & 174 & 139 & 126 & 104 & 56 \\
\hline Saratov region & 271 & 268 & 294 & 247 & 194 & 180 & 147 & 54 \\
\hline
\end{tabular}

In most regions from 1990 to 2018, the average daily water consumption from centralized water supply systems per cities' and villages' residents decreased by $30-46 \%$. In Rostov Region and Stavropol Territory it decreased 2 times and more. Its value is significantly affected by the indicator of the proportion of the available housing equipped with water supply systems and the share of the urban population in the total population.

The situation with the state of surface water of centralized drinking water supply and water quality at the water intakes in the Don River basin is generally improving [7, 8, 9]. In Saratov Region from 1997 to 2018 the proportion of polluted samples in reservoirs of the first category decreased from 32 to $12 \%$ (Fig.). In recent years, the proportion of polluted samples in Volgograd Region and Stavropol Territory has been very small. At the same time, Rostov region has high values of this indicator (with the exception of 2018). These indicators are very high in the Republic of Kalmykia (more than 50\%).

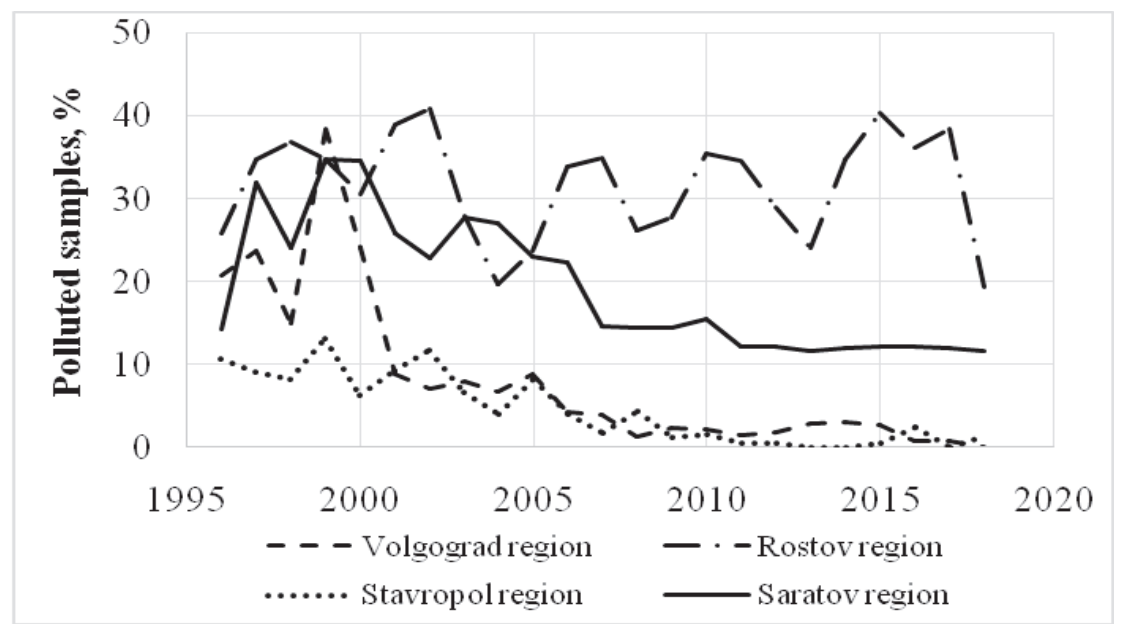

Fig. Dynamics of the share of studied water samples in water bodies used as sources for drinking water supply of the population that do not meet hygienic standards for sanitary and chemical indicators. 
The situation with water quality by microbiological indicators is very similar to the previous one. For 1996-2018 the proportion of unsatisfactory samples by microbiological indicators in reservoirs of the first category decreased in Saratov region from $30 \%$ to $6-7 \%$, and in Stavropol Territory from $39 \%$ to $10-15 \%$. At the same time, an increase in the indicator from 25 to $32-35 \%$ was noted in the Rostov Region.

Water supply of industrial enterprises requires high reliability $(\mathrm{P}>95 \%)$. On the Upper Don large industrial complexes of the cities of Lipetsk and Voronezh are located. The largest consumers in the Lower Don are industrial complexes of the cities of Volgodonsk, Novocherkassk, Shakhty, Rostov-on-Don, Azov and others. The largest water users in the Don River basin are power engineering facilities of interregional importance such as Novovoronezh NGS, Rostov NGS, Novocherkassk HPP, Stavropol HPP. Industry is the largest water consuming sector among all sectors of the economy in the studied area. In $201858.4 \%$ of total water was used for industrial consumption, although in the mid-1990s (a period of sharp decline in industrial production), this figure slightly exceeded $50 \%$.

After 1952 irrigated agriculture in the Don River basin began to actively develop. This happened because of putting into operation the main facilities of the Don main canal with the appropriate irrigation network for the first 100 thousand hectares of irrigated land in the Rostov Region [10]. However, since the beginning of the 1990s the area of irrigated land began to decrease significantly. The financial support of industry has ceased both from the water consuming households and from the water management operating organizations. The previously created centrally managed land melioration system in the country was practically destroyed. There was a sharp decline in the fleet of sprinkling and irrigation machines, the volume of repair work at pumping stations, canals, hydraulic structures, pipelines.

Significant areas of irrigated land were not watered because of the lack of equipment and spare parts, pipe breaks, deterioration of the repair base due to the disruption of stable economic relations, and the breakdown of brigades and links of irrigators. Thus, the decline rate of the areas of actually watered agricultural lands was much faster than the decline rate of the availability of irrigated land. For example, in the whole Don River basin the area of irrigated agricultural land for 1990-2000 decreased by 1.4 times, and the area of actually watered lands decreased by 2.4 times. In 2000 every second irrigated hectare was watered, comparing with 2016, when only every fourth hectare was watered [11].

The volume of water used for irrigation in the Don River basin over the past 27 years has decreased by more than 3 times: from 2,374 million $\mathrm{m}^{3}$ in 1990 to 764 million $\mathrm{m}^{3}$ in 2016. This process was especially rapid in the 1990s. Water consumption for irrigation decreased by 2.1 times for the period of 1990-1997. Herein after this indicator was steadily declining, however the decreasing was significantly slower.

In recent years, positive changes have taken place in the meliorative complex of Russia: federal funding has improved and gained greater stability, the size of financial participation in land melioration of local authorities and rural producers has increased, and the disposal rate of meliorated land has decreased. Concerning the established federal target program "Development of Land Melioration of Agricultural Land in Russia for 2014-2020", the revival of land melioration in the country has started and the area of irrigated land in the Don River basin began to grow a little.

In the $1980 \mathrm{~s}$ industrial water consumption decreased from 8.9 to $5.8 \mathrm{~km}^{3}$, despite the rapid growth of production in all sectors. This decrease was due to the active introduction of recycled and sequential water supply: the volume of used recycled water increased by a third over 10 years. From 1990 to 2018 the use of fresh water in the Don River basin for production needs decreased from 5.8 to $2.9 \mathrm{~km}^{3}$. The use of recycled and sequential water increased from 10.4 to $17.0 \mathrm{~km}^{3}$, and the volume of water used for total water supply grew from 16.2 to $20.0 \mathrm{~km}^{3}[2,3]$. The water rotation coefficient (the ratio of the volume of 
circulating and sequential water consumption to gross water consumption for production needs) increased from 64.2 to $85.3 \%$ during this period. During the years of economic depression and devastation, its growth was insignificant, while after 2000 it became very substantial.

\section{References}

1. Residential Sector and Household Services in Russia, Statistics Digest of Federal State Statistics Service (2007), 357 p.

2. Annex to the statistical digest "Housing in Russia. 2019" (Information by subjects of the Russian Federation) [URL]: https://www.gks.ru/folder/210/document/13234 (Accessed 10.12.2019).

3. Regions of Russia: Statistics Digest, 2 (2001), 827 p.

4. Federal State Statistics Service. Leakage and unaccounted water consumption [URL]: https://fedstat.ru/indicator/34034 (Accessed 19.09.2019).

5. Newsletter of Subsoil State on the territory of Russian Federation in 2010, iteration 34 (2011), $208 \mathrm{p}$.

6. Newsletter of Subsoil State on the territory of Russian Federation in 2017, iteration 41 (2018), $384 \mathrm{p}$.

7. Environmental protection in Russian Federation. Statistics Digest (2001), 229 p.

8. Environmental protection in Russian Federation. Statistics Digest (2010), 303 p.

9. Environmental protection in Russian Federation. Statistics Digest (2018), 125 p.

10. R.G. Djamalov, M.B. Kireeva, A.E. Kosolapov N.L. Frolova Water resources of the Don River basin and their environmental state GEOS (2017) 205 p.

11. Land Melioration Department of the Ministry of Agriculture of the Russian Federation: http://mcx-dm.ru. 